Canadian

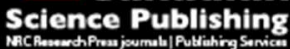

Canadian Journal of Zoology Revue canadienne de zoologie

\title{
Leeches (Annelida: Hirudinea) from the far north of Ontario: distribution, diversity, and diagnostics
}

\begin{tabular}{|r|l|}
\hline Journal: & Canadian Journal of Zoology \\
\hline Manuscript ID & cjz-2017-0078.R1 \\
\hline Manuscript Type: & Article \\
\hline Date Submitted by the Author: & 23-Aug-2017 \\
\hline Complete List of Authors: & $\begin{array}{l}\text { Langer, Sarah; Trent University } \\
\text { Vezsenyi, Kathryn; Trent University } \\
\text { de Carle, Danielle; University of Toronto } \\
\text { Beresford, David; Trent University, Biology } \\
\text { Kvist, Sebastian; Royal Ontario Museum, Department of Natural History; } \\
\text { University of Toronto, Department of Ecology and Evolutionary Biology }\end{array}$ \\
\hline Keyword: & $\begin{array}{l}\text { HIRUDINEA < Taxon, Leeches, northern Ontario, species distribution, } \\
\text { specimen records, checklist }\end{array}$ \\
\hline &
\end{tabular}

\section{SCHOLARONEm}

Manuscripts 
1 Leeches (Annelida: Hirudinea) from the far north of Ontario: distribution, diversity, and diagnostics

4

5 Sarah V. Langer ${ }^{1}$, Kathryn A. Vezsenyi ${ }^{1}$, Danielle de Carle ${ }^{2,3}$, David V. Beresford ${ }^{4}$, Sebastian Kvist $^{2,3, *}$

7

$8{ }^{1}$ Environmental and Life Sciences Graduate Program, Trent University, 1600 West Bank Drive, $9 \quad$ Peterborough Ontario, Canada, K9J 7B8, Canada

$10{ }^{2}$ Department of Natural History, Royal Ontario Museum, 100 Queen's Park, Toronto, Ontario, $11 \quad$ M5S 2C6, Canada

$12{ }^{3}$ Department of Ecology and Evolutionary Biology, University of Toronto, 25 Willcocks Street, 13 Toronto, Ontario, M5S 3B2, Canada.

$14{ }^{4}$ Biology Department, Trent University, 1600 West Bank Drive, Peterborough Ontario, Canada, $15 \quad$ K9J 7B8, Canada.

$16 *$ Corresponding author: E-mail: sebastian.kvist@utoronto.ca 


\section{Abstract}

Leeches have a worldwide distribution, yet numerous geographical regions remain to be

19 adequately surveyed. Here, we present leech species records for one of these regions: the far

20 north of Ontario. This region is primarily wetland habitat and includes two of Ontario's three

21 ecozones. Morphological examinations, and a single instance of successful DNA amplification

22 with subsequent molecular identification, allowed us to identify representatives of 12 species

23 from two predatory families (Erpobdellidae and Haemopidae) and one parasitic family

24 (Glossiphoniidae) among samples of 130 individuals. To provide a more inclusive list of species

25 records for this remote region, our data were also augmented by 25 largely unpublished

26 collection records (for 102 individuals) from the Canadian Museum of Nature, which revealed

27 the presence of an additional species. We comment on finds of particular interest in our sampling

28 with comparison to relevant literature, and provide new distribution data for these species. 29

30 Key Words: Hirudinea, leeches, northern Ontario, species distribution, specimen records, 31 checklist. 


\section{Introduction}

Leeches (Annelida: Hirudinea) are a globally distributed, sparsely diverse, but highly abundant group of annelids. They have been recorded from every ocean and every continent, and inhabit freshwater, marine, and terrestrial ecosystems alike. They are defined by the absence of parapodia and chetae, unpaired genital openings on the clitellum, and suckers on both ends of their elongate bodies (Sket and Trontelj 2008). Only half of the roughly 680 known species represent parasitic forms, which feed either on the blood of vertebrates or haemolymph of invertebrates; others are predaceous, scavenging or macrophagous, feeding on smaller invertebrates (Sket and Trontelj 2008; Bielecki et al. 2011). Leeches are a primary food source for numerous freshwater and marine fishes within their habitats (Clady 1974; Davies and Kasserra 1989; Koperski 2006), making them important components of aquatic food webs (Sawyer 1986; Adamiak-Brud et al. 2016). Because predaceous leeches are often found in abundance across ecosystems, they may act as useful gauges of water pollution (Bendell and McNicol 1989; Macova et al. 2009). Beyond their use as bioindicators, leeches are also frequently used in modern authoritative medicine, as relievers of venous congestion following flap or digit replantation surgery (e.g. Dabb et al. 1992; Soucacos et al. 1994). One of the key innovations granting them medical utility is their production of highly potent anticoagulants that keep the blood flowing in and around the incision site during the extended feeding period (Kvist et al. 2013, 2014, 2016; Siddall et al. 2016).

Approximately 480 of the 680 described leech species are associated with freshwater, with the remaining species classified as marine or terrestrial (Sket and Trontelj 2008). About 80 freshwater and terrestrial species have been recorded from North America (Moser et al. 2006; Sket and Trontelj 2008; Kubova et al. 2013), and Davies (1973) acknowledged 42 of these 
55 species as inhabiting Canada. Much like other cosmopolitan taxa, leech populations can shift in 56 the face of ecological changes in climate, biota, or landscape. Variance in substrate, for example, 57 can have a large impact on leech communities (Kubova et al. 2013): many species, like those in 58 the family Glossiphoniidae, use inchworm-type locomotion, such that their movement is 59 impeded by softer substrates (Adamiak-Brud et al. 2016). Environmental features such as rocks 60 and submerged logs assist with this type of movement and act as shelter, protecting them from 61 daylight, predators, and wave action (Adamiak-Brud et al. 2016); although, several leeches, e.g.

62 members of Hirudinidae and Macrobdellidae, are capable swimmers. Tracking changes that 63 might occur at a community level could be indicative of large-scale landscape alterations. Such 64 endeavours are contingent on comprehensive distribution records covering extended periods of 65 time. Hirudinea is just one of many taxa that have large gaps in knowledge regarding its detailed geographical distribution.

One such gap in our knowledge is the far north of Ontario, which covers 451,808 square kilometres (42\% of the province; Marshall and Jones 2011) as defined in Ontario's Far North Act of 2010 (S.O. 2010, c.18 s.2). This area includes two of Ontario's three ecozones: the Hudson Bay Lowlands, and the Ontario Shield (Crins et al. 2009). Ecozones are characterized

71 by physical processes that can be used to explain differences in the flora and fauna present (Crins

72 et al. 2009). The Hudson Bay Lowlands ecozone contains the third largest wetland in the world,

73 is the only area in Ontario influenced by oceanic currents, and has an area of continuous

74 permafrost that extends along the Hudson Bay coastline (Crins et al. 2009). The Ontario Shield 75 ecozone contains tens of thousands of lakes that range in size, depth, transparency, and shoreline 76 complexity (Marshall and Jones 2011). The larger lakes have been surveyed for fish since the

77 Patricia inventory in 1959 (Marshall and Jones 2011). Since then, extensive fieldwork has been 
conducted in Ontario's far north through the Ontario Ministry of Natural Resources and Forestry (OMNRF) Far North Biodiversity Project (FNBP). From 2009 to 2014, selected areas were surveyed using a variety of methods aimed at recording a diverse inventory of flora and fauna. The present study is based on these collection efforts and aims to provide insight into the composition of northern Ontario's hirudofauna. The first of its kind, our research may serve as a starting point for future studies investigating changes to population distributions as a result of biotic or abiotic influences.

\section{Methods}

Leech specimens were collected in the far north of Ontario by the FNBP between 2010 and 2014. Importantly, leeches were not necessarily the target taxa for these collection efforts, which likely resulted in fewer organisms collected, as compared to more leech-centric, targeted approaches. Individuals were most often captured using aquatic net and trap surveys. Aquatic net surveys used D-nets to sample freshwater habitats at scheduled times throughout the day. Aquatic traps were galvanized steel minnow traps baited with dog food and a ball of tinfoil intended to attract minnows - and left in the water for 24 hours before recovery. Four traps were placed at each locality. For detailed aquatic sampling methods from this project, see Goertz and Phoenix (2015). Two individual leeches were also caught in pitfall and pan trap surveys. Pitfall traps were constructed from $250 \mathrm{~mL}$ plastic cups, inserted into the ground and left for three days before recovery. Pan traps of blue, white, and yellow bowls were dug into shallow holes arranged in a cross, and were checked daily. Additionally, leeches were collected when observed outside of scheduled trapping methods, here referred to as incidental. Baited traps are often employed in leech-specific surveys to target sanguivorous and scavenging leech species, but this 
101 may bias catches based on feeding habits (Bendell and McNicol 1991). The surveys conducted 102 during this project were not intended to be leech-specific, allowing us the opportunity to sample 103 leeches using a number of methods, but potentially limiting our catches for some species. For 104 example, no large fish specimens were collected during the current project, which resulted in a 105 complete absence of fish leeches (Piscicolidae) - it is likely that extended fishing efforts would reveal several piscicolid species in the region. All collected specimens were preserved in $70 \%$ denatured ethanol. Leeches were sorted from these samples and brought to the Royal Ontario Museum (ROM) for identification and long-term curation. Identification was done according to specialized literature (e.g. Davies 1971, 1973; Klemm 1985; Sawyer 1986) and examination of specimens was conducted using a Leica Wild M10 dissecting microscope (Leica Microsystems)

111 fitted with a Spot Flex 15.264 megapixel camera (Spot Imaging). Several juvenile individuals 112 proved refractory to morphological identification and, for five of these, molecular identification 113 via DNA barcoding (see Hebert et al. 2003) using cytochrome $c$ oxidase subunit I (COI) was 114 attempted; for this purpose, DNA extraction, amplification and sequencing methods followed 115 Phillips et al. (2010). Molecular identification relied both on a BLAST approach (Altschul et al. 116 1997), and on a phylogenetic approach using the parsimony criterion. All COI sequences 117 pertaining to the genus Haemopis were downloaded from GenBank on August 21, 2017 and 118 these were then jointly aligned using the online version of MAFFT ver. 7 (Katoh and Standley 119 2013). A phylogenetic tree was then constructed using TNT (Goloboff et al. 2008); the analysis 120 employed 100 iterations, 5 rounds of ratcheting and 3 rounds of fusing. Because the tree is 121 intended to infer specimen identifications rather than relationships, the tree was mid-point 122 rooted. Maps were produced with ArcMap ver. 10.2 (Esri, 2011) using open sources outlines 123 from the OMNRF and an ecozone layer (Commission for Environmental Cooperation 2009). 
Our ROM-curated records were augmented by largely unpublished records in the online

125 database of the Canadian Museum of Nature (CMN). To increase the comprehensiveness of the

126 present study, 102 individuals collected at 25 localities, and representing 10 different species,

127 were included from the CMN database, only four of which have been previously published (see

128 Hovingh 2006).

129

130

Results

A total of 130 individual leeches were collected between 2010 and 2014, representing

132 three families: Erpobdellidae (n=51) (Fig. 1), Haemopidae (n=33) (Fig. 2), and Glossiphoniidae

$133(\mathrm{n}=46)$ (Fig. 3). Among these, 12 species were recorded, representing both predacious and

134 parasitic taxa. Locations (including GPS coordinates), dates, and methods of capture for all

135 specimens are listed in Table 1. Several specimens were damaged or juvenile, precluding

136 successful morphological identification. DNA extraction and amplification was attempted for

137 five individuals whose specific identities were unknown; however - likely due to long-term

138 preservation in relatively low concentrations of ethanol (70\%) - four of these attempts were

139 unsuccessful. As a result, these four individuals are only identified to genus level, as are juvenile

140 individuals and individuals in which the diagnostic features were obscured due to preservation

141 methods. Each species is briefly presented below, with location of capture summarized by

142 ecodistrict; this method of classifying the far north is described by Crins (2009). CMN records

143 are accompanied by the location descriptions from the museum's database.

144

145

Family Erpobdellidae

146

Erpobdella obscura (Verrill 1872) 
Fig. 4A

Specimens possess 4 pairs of anterior eyes ( 2 anterior pairs and 2 posterior pairs);

variable pigmentation, most often with relatively small, scattered black blotches on a lighter background; and 2 annuli between gonopores (in furrows between annuli). One specimen was opened to reveal a spirally-coiled atrial cornua. All of these characters suggest that the specimens belong to Erpobdella obscura. This species was one of the most abundant among the samples and individuals were collected from the ecodistricts Sandy Lake, Wunnummin Lake, Albany River, Winisk River, Dickey River, and Lower Sachigo River. In addition, three records (five individuals) of this species were available in the CMN database; these were collected from "between Mattic and Opazatika River", Moose Factory, and "North Point, 29 km north of Moosonee", respectively (Table 1).

\section{Erpobdella punctata (Leidy 1870)}

Figure 4B

Members of Erpobdella punctata exhibit remarkable variation in dorsal pigmentation patterns, but all possess 2 or 4 longitudinal rows of darkly pigmented dots; these dots are sometimes fused into laterally oriented black bars, which can occasionally be interpreted as continuous stripes of pigmentation. This species is moderate to large in size (up to $100 \mathrm{~mm}$ ), has gonopores separated by 2 annuli (with large male pore), and 3 pairs of eyes. Erpobdella punctata is abundant throughout southern Canada (Davies 1973; Klemm 1985), but the northernmost limit of its distribution is still unclear. The three specimens were collected from three different ecodistricts: Lower Sachigo River, Wunnumin Lake, and Winisk River. Two additional records from south of Albany River and Moose Factory were present in the CMN database (Table 1). 
170

171

172

173

174

175

176

177 178 (Table 1).

179

180

181

182

183

184

185

186

187

188

189

190

191

192
Erpobdella parva (Moore 1912)

Figure 4C

Specimens possess gonopores separated by $3 \frac{1}{2}$ annuli, with the male gonopore elevated on a ring, 4 pairs of eyes ( 2 posterior pairs of labial eyes behind the anterior 2 pairs), uniform dorsal colouration and absence of a mid-dorsal stripe. Collectively, these characters identify Erpobdella parva. Only a single individual of this species was collected from the Wunnummin Lake ecodistrict and a single record from the Winisk tributary existed in the CMN database

Erpobdella dubia (Moore and Meyer 1951)

Fig. 4D

Members of Erpobdella dubia possess a dark, mid-dorsal, longitudinal stripe that immediately sets them apart from most other species of Erpobdella. In addition, the dorsum is often greenish in colour and heavily mottled, gonopores are normally separated by $3 \frac{1}{2}$ annuli

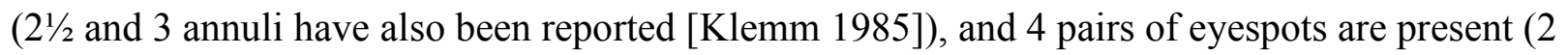
posterior pairs of labial eyes behind the anterior 2 pairs). A single specimen of Erpobdella dubia was collected from the Lower Sachigo River ecodistrict; one record was also available from the CMN database, collected from "narrows at source of Shell Brook" (Table 1). 
194 the oral sucker, no jaws, 12 pharyngeal folds, and black blotches of dorsal pigmentation (or 195 entirely black background with beige or light green blotches), as is diagnostic for the species 196 (Klemm 1985). A total of four individuals were collected from three different ecodistricts:

197 Wunnummin Lake, Sandy Lake, and Lower Kenogami Lake. Two individuals were recorded 198 from the CMN database, both collected from Fort Albany, $1.5 \mathrm{~km}$ west of Albany River (Table 199 1). presence of jaws with 12-16 teeth, a caudal sucker that was about half the width of the widest part of the body, and a uniformly grey dorsal colouration with moderate to heavy black, irregular blotching. Superficially, this species resembles $H$. grandis but is distinguished therefrom by the 207 presence of jaws, and by the general size of the adult forms: H. grandis grows to be almost twice 208 as long as H. marmorata (Klemm 1985). Haemopis marmorata was the most abundant species 209 among our samples, and was represented by 24 individuals from five different ecodistricts:

210 Wunnummin Lake, Lower Sachigo River, Albany River, Winisk River, and Dickey River.

211 Another four records for this species existed in the CMN database and these were collected from 212 the Albany River, Moosonee District $3 \mathrm{~km}$ from Partridge River, west of Fort Severn and Moose 213 Factory (see Table 1). 
Fig. 5C

A single individual presents morphological characters that suggest an affinity with Haemopis lateromaculata. The specimen possesses a green dorsum with heavy dark blotching and few scattered yellow blotches, a darker venter with few indistinct dark or yellow pigmentation blotches, a caudal sucker broadly attached by a pedicel, and jaws with 10-12 teeth. This individual was collected from the Wunnummin Lake ecodistrict (Table 1). In addition, four records exist in the CMN database [identity adopted from Hovingh (2006), the database lists one record without a species identification, and the others as $H$. marmorata]. These were collected from "North-northeast of east end of Anderson Island in Albany River", "between Mattis and Opazatika River Missinabi River", "North end of lake near outlet Severn Lake" and "between new post M.B.C. and Moose River Abitibi River” (see Table 1). Because of this species’ resemblance to $H$. marmorata, this specimen was subjected to DNA sequencing to enable robust molecular identification via DNA barcoding of the COI locus (GenBank accession number MF706261). The resulting sequence was BLASTed against GenBank's non-redundant (nr.) nucleotide sequence database using a BLASTn protocol. The closest match recovered was to Haemopis terrestris (Forbes 1890), but these sequences still showed 14\% difference. When constraining the BLAST search against $H$. lateromaculata (only a single COI sequence available on GenBank), the sequences showed $18 \%$ dissimilarity. Moreover, in the tree resulting from the phylogenetic analysis (Supplementary Figure S1) of the COI region, the new specimen was located on a long branch, and did not nest closely with other species, suggesting that this taxon is not otherwise represented in the dataset. The identification of our specimen as Haemopis cf. lateromaculata should therefore be viewed with appropriate caution - it could be that this 
238 specimen represents undescribed diversity or, alternatively, that the COI sequence for $H$.

239 lateromaculata in GenBank is mislabelled.

240

\section{Family Glossiphoniidae}

Helobdella stagnalis (Linnaeus 1758)

Figure 6A

Specimens are small (often less than $1 \mathrm{~cm}$ ); possess a dorsal, nuchal, chitinous scute on somite VIII; and are light grey or beige in color. Much like Haemopis marmorata, the abundance of Helobdella stagnalis was relatively high compared to that of most other species: 23 individuals were collected from four different ecodistricts (Wunnumin Lake, Sandy Lake, Albany River and Lower Sachigo River; and, two records (6 adults and 71 juveniles) for this species are present in the $\mathrm{CMN}$ database, both of which were collected from the Attawapiskat River (Table 1). The taxonomic history of this species and its constituents is rather muddled. Historically, individuals bearing a distinct nuchal scute have all been identified as $H$. stagnalis but, concurrently with our growing knowledge of species boundaries, several other nuchal scutebearing species have been described (e.g. Siddall 2001; Oceguera-Figueroa et al. 2010; SalasMontiel et al. 2014; Beresic-Perrins et al. 2017), some with geographic distributions overlapping that of $H$. stagnalis. Indeed, the boundaries between nuchal scute-bearing species are obscured, and a thorough revision of the genus is direly needed. All of the specimens examined here show morphological characters that are compatible with those of H. stagnalis. 

Our specimens of Glossiphonia elegans possess 3 pairs of eyes arranged in parallel (i.e.,

262

263

264

265

266

267

268

269

270

271

272

273

274

275

276

277

278

279

280

281

282

283

not in an arch-like manner), a pair of dark paramedial stripes dorsally and ventrally, interrupted by metameric white spots (sometimes lacking from juvenile individuals), and an opaque body with beige to green or gray colouration. Molecular data have suggested that the North American form of the species commonly identified as Glossiphonia complanata (Linnaeus 1758) may not be conspecific with its European counterpart (Siddall et al. 2005). As a result, Siddall et al. (2005) resurrected the specific epithet Glossiphonia elegans to represent the North American form. The specimens were collected from the ecodistricts of Sandy Lake, Albany River, Dickey River, Wunnummin Lake and Lower Sachigo River; in addition, four records for this species exist in the CMN database, and these were collected from Moose Factory, "Winisk 100 metres from east bank of river, $14 \mathrm{~km}$ upstream from village", "10 km west of Attawapiskat Monument Channel" and at outlet of Stout Lake (Table 1).

\section{Placobdella rugosa (Verrill 1874)}

Fig. 6C

The single specimen of Placobdella rugosa possesses heavy dorsal papillation with 5 rows of more prominent papillae, lateral margins with alternating light and dark pigmentation (in the order of light, light, dark, light, light, dark, etc.) and scattered dark chromatophores on the ventral and anterodorsal surfaces. The identification of members of Placobdella, particularly the papillated forms, is fraught with difficulty, and the taxonomy of Placobdella rugosa is no exception. The species was originally described as a subspecies of Placobdella ornata (Verrill 1872), subsequently elevated to full species status, reassigned to $P$. ornata, and finally resurrected in 2012 (Moser et al. 2012, and references therein). The species is abundant across 
284 Canada and is associated with varying climates and faunas (Klemm 1982, de Carle et al. 2017).

285 This particular specimen was collected from the Sandy Lake ecodistrict (Table 1).

286

287

288

289

290

291

292

293

294

295

296

297

298

299

300

301

302

303

304

305

306

\section{Placobdella montifera Moore 1906}

Whereas the newly collected material did not include individuals pertaining to

Placobdella montifera, the collections from CMN do include one record. This species occurs in Ontario and westward across Canada (Davies 1973), and can be distinguished readily by its 3 prominent pointed keels or ridges on the dorsal surface - no other species of Placobdella possess this character - and its constricted neck region, resulting in a discoid head. This specimen was collected from Central Patricia Crow River (Table 1).

Theromyzon rude (Baird 1869)

Fig. 6D

A single specimen of Theromyzon rude was collected from the Sandy Lake ecodistrict (no species records were available from the CMN database; Table 1). It possesses 2 annuli between gonopores, a gelatinous and slightly transparent body with 2 paramedial rows of brown spots on the dorsum. Members of this genus are typically distinguished from congeners by the number of annuli between gonopores, but Baird (1869) failed to note the number of annuli in his original description of T. rude. Based on material collected from the type locality, Moore and Meyer (1951) and Meyer and Moore (1954) re-described the species and noted 3 annuli between gonopores. Later, the original type material was re-examined by Oosthuizen and Davies (1992) who noted that only 2 annuli separated the gonopores; the confused species, with 3 annuli between gonopores, was subsequently described by Davies and Oosthuizen (1993). As a result, 
307 much uncertainty has surrounded the taxonomy of the species. The problem was exacerbated by

308 the resulting difficulties in separation of T. rude sensu lato and Theromyzon biannulatum Klemm

3091977 , both of which possess 2 annuli between gonopores. Notwithstanding that our specimen is

310 compatible with the morphology of $T$. rude, we concede that a taxonomic revision of the group,

311 including molecular techniques, is needed before robustly inferring the identity of any specimen

312 of Theromyzon with 2 annuli between gonopores.

\section{Theromyzon tessulatum (Müller 1774)}

Fig. 6E

317 lines on the dorsum. Four leech individuals (one adult and a brood of three juveniles) were 318 collected in the Lower Sachigo River ecodistrict (no specimen records were available in the 319 CMN database; Table 1). As opposed to the congeneric T. rude, this species is distinct and 320 therefore more easily identified by virtue of the 4 annuli separating the gonopores. This species 321 was thought to be confined to Europe but it is now understood that its distribution is transatlantic 322 (Pawlowski 1948; Herrman 1970; Klemm 1977, 1982; Davies 1973). The origin of this 323 distribution is indeed intriguing, seeing as this species is often encountered attached to, and 324 feeding from, waterfowl, which may explain its spread and current range.

\section{Discussion}

Of the 42 species of leeches that were recorded in the last comprehensive study of

328 Canada's hirudofauna (Davies 1973), 33 are non-piscicolid taxa. Members of Piscicolidae are 329 almost exclusively encountered attached to their fish hosts, but the remaining species can 
330 perhaps be more easily collected from rocks and debris. Of these 33 species, 25 have previously

331 been recorded from Ontario (Davies 1973). In total, 12 species were recovered from our newly

332 collected samples, and one additional species was recorded in the database of the Canadian

333 Museum of Nature. It is remarkable that, despite the harsh winter climates in northern Ontario

334 (including the area of continuous permafrost on the northern coast), 52\% of Ontario's known

335 non-piscicolid leech diversity is also recovered from the far north of the province. Taken

336 together, the collection sites cover a substantial part of this region and, as far as the authors can

337 tell, eight of the twelve species records are first reported in the present study (see Hovingh 2006).

338 Some of the species recovered herein are more or less ubiquitous across Canada, but some

339 represent taxa that are only infrequently recovered. Below, we discuss records of particular

340 interest and provide a general discussion on species distributions across North America in

341 general, and Ontario in particular.

342 Members of Erpobdellidae are considered widespread and some species, e.g. Erpobdella

343 punctata, have been described as the most commonly encountered and widely distributed leeches

344 in North America (Sawyer 1970; Klemm 1985; Kutschera and Wirtz 2001), though only three

345 individuals were present among the newly collected samples. In contrast, other species within the

346 genus, such as Erpobdella parva, have been recorded relatively infrequently (Klemm 1982); this

347 species is represented by a single specimen among our samples. Given their abundance

348 throughout North America, it is likely that species of Erpobdella play important roles in the

349 ecosystems they inhabit, and it is already known that they represent a significant source of food

350 for several freshwater fish species (e.g. Sinha and Jones 1967; Clady 1974; Davies and Kasserra

351 1989; Koperski 2006). 
Of the haemopid species recovered, Haemopis grandis and H. marmorata are considered

353 common and widely distributed in North America, with H. grandis being especially well represented in the Great Lakes region (Klemm 1982). Haemopis lateromaculata has more

355 recently been described as widely distributed in North America (Hovingh 2006). Members of the 356 genus are known to be amphibious (Madill and Hovingh 2007), yet only Haemopis terrestris

357 (Forbes 1890) is described as fully terrestrial. It is worth noting, however, that the distinction 358 between amphibious and terrestrial is sometimes difficult to accurately identify: many primarily aquatic leeches of the order Arhynchobdellida are known to spend time foraging and depositing cocoons on land immediately surrounding freshwater habitats (Siddall and Burreson 1996). Interestingly, two specimens of an unknown species of Haemopis were collected in terrestrial traps, but these specimens do not conform to the morphological description of Haemopis terrestris. The specimens lack a median longitudinal stripe and possess jaws with distichous

364 teeth and a relatively narrow caudal sucker, suggesting that they belong to Haemopis marmorata. 365 However, because of the terrestrial nature of these collecting events, we have refrained from 366 providing a specific epithet for these individuals. Freshly collected material from which DNA 367 can be extracted and successfully amplified will likely shed light on the identity of these 368 unknown leeches. oligochaetes and insect larvae, to snails, small crustaceans, and dead fish (Sawyer 1972, Barton

371 and Metcalfe 1986; Kutschera and Wirtz 2001; Moser et al. 2006). Moreover, previous

372 expeditions have successfully collected representatives of both genera using aquatic traps baited

373 with beef liver and ground beef (de Carle et al. 2017). Predacious leeches swallow their prey 374 either whole or in pieces (Kutschera and Wirtz 2001; Pfeiffer et al. 2005; Sket and Trontelj 
375 2008). For the present study, one specimen of a Haemopis species was caught in an aquatic trap

376 while feeding on an adult predaceous diving beetle (Dytiscidae: Dytiscus dauricus) (Fig. 7). A

377 similar observation was made by Bielecki et. al. (2011), wherein Haemopis sanguisuga was

378 collected in the act of feeding on a predaceous diving beetle larva (Dytiscus marginalis). Species

379 of Haemopis are opportunistic feeders, and are frequently found with exoskeletons of larval

380 aquatic insects in their digestive tracts (Moser et al. 2006).

381

All of the newly collected glossiphoniid species are considered common and widespread

382 (Klemm 1982). Glossiphonia complanata (the European counterpart to the North American G.

383 elegans; Siddall et al. 2005) and Helobdella stagnalis are considered some of the most widely

384 distributed species in Europe (Kutschera and Wirtz 2001) and are also commonly encountered

385 across North America (Klemm 1985). Although Theromyzon is considered holarctic (Mason et

386 al. 2005), members of this genus are less frequently encountered than other glossiphoniids

387 (Klemm 1982). This may be a function of their particular host affinity: members of Theromyzon

388 have a propensity to feed on birds (Mason et al. 2005), an association which may also explain

389 why they are so widely distributed across the landscape (Sket and Trontelj 2008).

390 Glossiphoniids are unique among leeches, in that they exhibit a high degree of parental

391 care (Siddall et al. 2005). Leeches of this family produce membranous cocoons - unlike the

392 hardened or spongy cocoons of other leeches - which are attached to the venter of the parent, and

393 carried until the offspring hatch. After hatching, the juvenile leeches remain attached to their

394 parent until being transported to their first meal (Siddall et al. 2005). Members of

395 Glossiphoniidae mainly employ a parasitic lifestyle, feeding on the blood of vertebrates or the

396 haemolymph of invertebrates (Siddall et al. 2005), though some may also eat small prey (Sket

397 and Trontelj 2008). Species of Placobdella are primarily ectoparasitic on aquatic reptiles and 
398

399

400

401

402

403

404

405

406

407

408

409

410

411

412

413

414

415

416

\section{Acknowledgments}

amphibians, though some are known to feed on fish, and many will feed opportunistically on other vertebrates such as birds and humans (Sawyer 1972; Jones and Woo 1990; Siddall and Gaffney 2004; Siddall and Bowerman 2006; Moser et al. 2014). Oddly, only a single specimen of Placobdella rugosa was newly collected and one additional record of Placobdella montifera was available in the CMN database. This paucity of Placobdella diversity and abundance starkly contrasts that of the southern parts of the province. Indeed, 8 species of Placobdella are currently known from Ontario (Davies 1973; Klemm 1985; de Carle et al. 2017), some of which are commonly encountered in high densities (de Carle et al. 2017).

Each of the collected families shows widespread distribution in the far north, and is seemingly not limited by ecozone - including the area of continuous permafrost on Ontario's northern coast. By and large, the diversity of leeches recorded from the far north of Ontario is lower than the diversity recovered in the southern regions (possibly as a result of more leechdirected research in southern Ontario), and the species composition of natural populations seems to be somewhat different between the two regions. This may reflect biotic or abiotic barriers to dispersal that are difficult to conquer. Future studies of leech species distributions across Canada that incorporate diversity from northern provinces and territories as well as northern regions of southern provinces, will likely evince the mechanisms that have produced distributions among these economically and ecologically influential organisms.

The authors thank the Ontario Ministry of Natural Resources and Forestry's Northeast Science and Information Section and Wildlife Research and Development Section for project coordination and logistics, and Far North Branch for funding of the Far North Biodiversity 
421 Project. We give special thanks to Dean Phoenix and the field crews of the Far North

422 Biodiversity Project. We also thank the First Nations communities of Peawanuck, Marten Falls,

423 Webequie, Nibinamik, Kitchenuhmaykoosib Inninuwug, Keewaywin, Fort Albany, and Fort

424 Severn for their hospitality and support for working on their traditional lands. We thank the field

425 crews who collected and provided the samples used in this paper. Finally we thank Sherri

426 DeGasparro for providing the identification on our dytiscid beetle and Don Stacey and Shannon

427 Asencio for provding technical assistance. Peter Trontelj (University of Ljubljana) provided

428 excellent feedback that greatly improved an earlier version of the manuscript. SK was funded by

429 an NSERC discovery grant and a scholarship from the Olle Engkvist Byggmästare Foundation.

430

$431 \quad$ References

432 Adamiak-Brud, Ż., Bielecki, A., Kobak, J., and Jabłońska-Barna, I. 2016. Rate of short-term colonization and distribution of leeches (Clitellata: Hirudinida) on artificial substrates. J. Zool. (Lond.) 299: 191-201.

Altschul, S.F., Madden, T.L., Schäffer, A.A., Zhang, J., Zhang, Z., Miller, W., and Lipman, D.J., 436 1997. Gapped BLAST and PSI-BLAST: a new generation of protein database search programs. Nucleic Acids Res. 25: 3389-3402.

Baird, W. 1869. Descriptions of some new sectorial Annelides in the collection of the British Museum. Proc. Zool. Soc. Lond. 1869: 310-318.

Barton, D.R., and Metcalfe, J.L. 1986. Life cycles, reproduction, and diets of Dina dubia and Erpobdella punctata (Hirudinea: Eropobdellidae) in Canagagigue Creek, Ontario. Can. J. Zool. 64: 640-648. 
443 Bendell, B.E., and McNicol, D.K. 1991. An assessment of leeches (Hirudinea) as indicators of 444 lake acidification. Can. J. Zool. 69: 130-3.

445 446

447

448 449

450 451

452 453 454 455 456 457 458 459 460 461 462 463 464 465

Beresic-Perrins, R.K., Govedich, F.R., Banister, K., Bain, B.A., Rose, D., and Shuster, S.M., 2017. Helobdella blinni sp. n. (Hirudinida, Glossiphoniidae) a new species inhabiting Montezuma Well, Arizona, USA. ZooKeys, 661: 137-155.

Bielecki, A., Cichocka, J.M., Jeleń, I., Świątek, P., and Adamiak-Brud, Ż. 2011. A checklist of leech species from Poland. Wiadomości Parazytologiczne, 57: 11-20.

Clady, M.D. 1974. Food habits of yellow perch, smallmouth bass and largemouth bass in two unproductive lakes in northern Michigan. Am. Midl. Nat. 91: 453-459.

Commission for Environmental Cooperation. 2009. Ecological regions of North America geospatial data presentation form: vector digital data. Montreal, Qu: Commission for environmental cooperation. Digital Media.

Crins, W.J., Gray, P.A., Uhlig, P.W.C., and Wester, M.C. 2009. The Ecosystems of Ontario, Part I: Ecozones and Ecoregions. Science and Information Branch, Inventory, Monitoring and Assessment, Ontario Ministry of Natural Resources, Peterborough Ontario.

Dabb, R.W., Malone, J.M., and Leveret, L.C. 1992. The use of medicinal leeches in the salvage of flaps with venous congestion. Ann. Plast. Surg. 29: 250-256.

Davies, R.W. 1971. A key to the freshwater Hirudinoidea of Canada. J. Fish. Res. Board Can. 28: 543-552.

Davies, R.W. 1973. The geographic distribution of freshwater Hirudinoidea in Canada. Can. J. Zool. 51: 531-545.

Davies, R.W., and Kasserra, C.E. 1989. Foraging activity of two species of predatory leeches exposed to active and sedentary prey. Oecologia, 81:329-334. 
468

469

470

471

472

473

474

475

476

477

478

479

480

481

482

483

484

485

486

487

Davies, R.W., and Oosthuizen, J.H. 1993. A new species of duck leech from North America formerly confused with Theromyzon rude (Rhynchobdellida: Glossiphoniidae). Can. J. Zool. 71: 770-775.

de Carle, D., Oceguera-Figueroa, A., Tessler, M., Siddall, M.E., and Kvist, S. 2017. Phylogenetic analysis of Placobdella (Hirudinea: Rhynchobdellida: Glossiphoniidae) with consideration of COI variation. Mol. Phylogenet. Evol. 114: 234-248.

Environmental systems research institute (ESRI). (2011). ArcGIS desktop version 10.2. USDA, Redlands, CA.

Forbes, S.A. 1890. An american terrestrial leech. Am. Nat. 24: 646-649.

Goertz, D.E., and Phoenix, R.D. 2015. Range extensions for northern redbelly dace (Chrosomus eos), fathead minnow (Pimephales promelas), and Iowa darter (Ethestoma exile) in Ontario, Canada. Can. Field-Nat. 129: 237-9.

Goloboff, P.A., Farris, J.S., and Nixon, K.C. 2008. TNT, a free program for phylogenetic analysis. Cladistics, 24: 774-786.

Herbert, P.D., Ratnasingham, S., and deWaard, J.R. 2003. Barcoding animal life: cytochrome c oxidase subunit 1 divergences among closely related species. Proc. R. Soc. Lond. B. Biol. Sci. (Supplemental) 270: S96-S99.

Herrman, S.J. 1970. Systematics, distribution, and ecology of Colorado Hirudinea. Am. Midl. Nat. 83: 1-37.

Hovingh, P. 2006. The leech Haemopis lateromaculata (Hirudinea: Haemopidae): its North America distribution and additional notes on species description. Can. Field-Nat. 120: $443-451$ 
488 Jones, S.R.M., and Woo, P.T.K. 1990. Redescription of the leech Desserobdella phalera (Graf, 489 1899) n. comb. (Rhynchobdellida: Glossiphoniidae), with notes on its biology and 490 491 492 493 494 495 496 497 498 499 500 501 502 503 504 505 506 507 508 509 occurrence on fishes. Can. J. Zool. 68: 1951-1955.

Katoh, K., and Standley, D.M. 2013. MAFFT multiple sequence alignment software version 7: improvements in performance and usability. Mol. Biol. Evol. 30: 772-780.

Klemm, D.J. 1982. Leeches (Annelida: Hirudinea) of North America. U.S. Environmental Protection Agency: Office of research and development, Cincinnati Ohio. 1-177.

Klemm, D.J. 1985. Freshwater leeches (Annelida: Hirudinea). A guide to the freshwater Annelida (Polychaeta, Naidid and Tubificid Oligochaeta, and Hirudinea) of North America. Kendall/Hunt Publishing Co., Dubuque.

Koperski, P. 2006. Relative importance of factors determining diversity and composition of freshwater leech assemblages (Hirudinea; Clitellata): a meta analysis. Arch. Hydrobiol. 166: $325-341$.

Kubová, N., Schenková, J., and Horsák, M. 2013. Environmental determinants of leech assemblage patterns in lotic and lenitic habitats. Limnologica, 43: 516-524.

Kutschera, U., and Wirtz, P. 2001. The evolution of parental care in freshwater leeches. Theory in Biosciences, 120: 115-37.

Kvist, S., Gi-Sik, M., and Siddall, M.E. 2013. Diversity and selective pressures of anticoagulants in three medicinal leeches (Hirudinida: Hirdinidae, Macrobdellidae). Ecol. Evol. 3: 918933.

Kvist, S., Brugler, M.R., Goh, T.G., Giribet, G., and Siddall, M.E. 2014. Pyrosequencing the salivary transcriptome of Haemadipsa interrupta (Annelida: Clitellata: Haemadipsidae): 
anticoagulant diversity and insight into the evolution of anticoagulation capabilities in leeches. Invertebr. Biol. 133:74-98.

Kvist, S., Oceguera-Figueroa, A., Tessler, M., Jiménez-Armenta, J., Freeman Jr., R.M., Giribet, G., and Siddall, M.E. 2016. When predator becomes prey: investigating the salivary transcriptome of the shark-feeding leech Pontobdella macrothela (Hirudinea: Piscicolidae). Zool. J. Linn. Soc. 179: 725-737.

Macova, S., Harustiakova, D., Kolarova, J., Machova, J., Zlabek, V., Vykusova, B., Randak, T., Velisek, J., Poleszczuk, G., Hajslova, J., Pulkrabova, J., and Svobodova, Z. 2009. Leeches as sensor-bioindicators of river contamination by PCBs. Sensors, 9: 1807-1820.

Madill, J., and Hovingh, P. 2007. Freshwater leech (Annelida: Hirudinida) distribution in the Canadian Province of Newfoundland and Labrador and adjacent regions: check-list, new records, new pigmentation forms, and Pleistocene refugia. Zootaxa, 1657: 1-21.

Marshall, T.R., and Jones, N.E. 2011. Aquatic Ecosystems of the Far North of Ontario: State of Knowledge. Ontario Legislative Library, Toronto, Ontario, Canada.

Mason, T.A., Sayers, C.W., Paulson, T.L., Coleman, J., and Shain, D.H. 2005. Cocoon deposition and hatching in the aquatic leech, Theromyzon tessulatum (Annelida, Hirudinea, Glossiphoniidae). Am. Midl. Nat. 154: 78-87.

Meyer, M.C., and Moore, J.P. 1954. Notes on Canadian leeches (Hirudinea), with the description of a new species. Wasmann J. Biol. 12: 63-96.

Moore, J.P., and Meyer, M.C. 1951. Leeches (Hirudinea) from Alaskan and adjacent waters. Wasmann J. Biol. 9: 11-77. 
531 Moser, W.E., Klemm, D.J., Richardson, D.J., Wheeler, B.A., Trauth, S.E., and Daniels, B.A.

532 2006. Leeches (Annelida: Hirudinida) of Northern Arkansas. J. Ark. Acad. Sci. 60: 8495.

534

535

536

537

538

539

540

541

542

543

544

545

546

547

548

549

550

551

552

Moser, W.E., Richardson, D.J., Hammond, C.I., and Lazo-Wasem, E.A. 2012. Redescription of Placobdella ornata (Verrill, 1872) (Hirudinida: Glossiphoniidae). Bull. Peabody Mus. Nat. Hist. 53: 325-330.

Moser, W.E., Bowerman, J., Hovingh, P., Pearl, C.A., and Oceguera-Figueroa, A. 2014. New host and distribution records of the leech Placobdella sophieae Oceguera-Figueroa et al. 2010 (Hirudinida: Glossiphoniidae). Comp. Parasitol. 81: 199-202.

Oceguera-Figueroa, A., León-Règagnon, V., and Siddall, M.E. 2010. DNA barcoding reveals Mexican diversity within the freshwater leech genus Helobdella (Annelida: Glossiphoniidae). Mitochondrial DNA, 21: 24-29.

Oosthuizen, J.H., and Davies, R.W. 1992. Redescription of the duck leech, Theromyzon rude (Baird, 1869) (Rhynchobdellida: Glossiphoniidae). Can. J. Zool. 70: 2028-2033.

Pfeiffer, I., Brenig, B., and Kutschera, U. 2005. Molecular phylogeny of selected predacious leeches with reference to the evolution of body size and terrestrialism. Theory in Biosciences, 124: 55-64.

Phillips, A.J., Arauco-Brown, R., Oceguera-Figueroa, A., Gomez, G.P., Beltrán, M., Lai, Y.T., and Siddall, M.E. 2010. Tyrannobdella rex n. gen. n. sp. and the evolutionary origins of mucosal leech infestation. PLoS ONE, 5: e10057.

Pawlowski, L.K. 1948. Contribution a la systematique des sangsues du genre Erpobdella de Blainville. Acta Zoologica et Oecologica, Universitatis Lodziensis, 8: 55. 
553 Salas-Montiel, R., Phillips, A.J., De Leon, G.P.P., and Oceguera-Figueroa, A. 2014. Description

554

555

556

557

558

559

560

561

562

563

564

565

566

567

568

569

570

571

572

573

574

575

of a new leech species of Helobdella (Clitellata: Glossiphoniidae) from Mexico with a review of Mexican congeners and a taxonomic key. Zootaxa, 3900: 77-94.

Sawyer, R.T. 1970. Observations on the natural history and behavior of Erpobdella punctata (Leidy)(Annelida: Hirudinea). Am. Midl. Nat. 83: 65-80.

Sawyer, R.T. 1972. North American freshwater leeches, exclusive of the Piscicolidae, with a key to all species. Illinois Biological Monographs 46: University of Illinois press. 1-154.

Sawyer, R.T. 1986. Leech biology and behaviour. Vol. 1. Oxford: Clarendon Press.

Siddall, M.E., and Burreson, E.M. 1996. Leeches (Oligochaeta?: Euhirudinea), their phylogeny and the evolution of life-history stratgeies. Hydrobiologia, 334: 227-285.

Siddall, M.E. 2001. Leeches of Laguna Volcán, Bolivia, including a new species of Helobdella (Clitellata: Hirudinea). Am. Mus. Novit. No. 3313: 1-12.

Siddall, M.E., and Gaffney, E.S. 2004. Observations on the leech Placobdella ornata feeding from bony tissues of turtles. J. Parasitol. 90: 1186-1188.

Siddall, M.E., Budinoff, R.B., and Borda, E. 2005. Phylogenetic evaluation of systematics and biogeography of the leech family Glossiphoniidae. Invertebr. Syst. 19:105-112.

Siddall, M.E., and Bowerman, J. 2006. A new species of glossiphoniid leech from Rana pretiosa (Amphibia: Ranidae) in Oregon. J. Parasitol. 92: 855-7.

Siddall, M.E., Brugler, M., and Kvist, S. 2016. Comparative transcriptomic analyses of 3 species of Placobdella (Rhynchobdellida: Glossiphoniidae) confirms a single origin of blood feeding in leeches. J. Parasitol. 102: 143-150.

Sinha, V.R.P., and Jones, J.W. 1967. On the food of the freshwater eels and their feeding relationships with salmonids. J. Zool. (Lond.) 153: 119-137. 
576 Sket, B., and Trontelj, P. 2008. Global diversity of leeches (Hirudinea) in freshwater.

$577 \quad$ Hydrobiologia, 595: 129-137.

578 Soucacos, P.N., Beris, A.E., Malizos, K.N., Kabani, C.T., and Pakos, S. 1994. The use of

579 medicinal leeches, Hirudo medicinalis, to restore venous circulation in trauma and

580 reconstructive microsurgery. Int. Angiol. 13: 251-258.

581

582 


\section{$583 \quad$ Figure legends}

584 Figure 1. Distribution of leech samples of the family Erpobdellidae, collected for the present

585 study across the far north of Ontario’s two ecozones; Hudson Bay Lowlands and Ontario Shield.

586 Projection: Canadian Lambert Conformal Conic, Datum: NAD 1983.

587

588 Figure 2. Distribution of leech samples of the family Haemopidae, collected for the present study 589 across the far north of Ontario's two ecozones; Hudson Bay Lowlands and Ontario Shield.

590 Projection: Canadian Lambert Conformal Conic, Datum: NAD 1983.

591

592 Figure 3. Distribution of leech samples of the family Glossiphoniidae, collected for the present 593 study across the far north of Ontario's two ecozones; Hudson Bay Lowlands and Ontario Shield. 594 Projection: Canadian Lambert Conformal Conic, Datum: NAD 1983.

595

596 Figure 4. Dorsal views of select representative specimens of Erpobdellidae from the newly

597 collected material; scale bars represent $0.5 \mathrm{~cm}$. (A) Erpobdella obscura (ROMIZ I12051), (B)

598 Erpobdella punctata (ROMIZ I12062), (C) Erpobdella parva (ROMIZ I12072), (D) Erpobdella 599 dubia (ROMIZ I12101).

600

601 Figure 5. Dorsal views of select representative specimen of Haemopidae from the newly

602 collected material; scale bars represent $1 \mathrm{~cm}$. (A) Haemopis grandis (ROMIZ I12001), (B)

603 Haemopis marmorata (ROMIZ I12015), (C) Haemopis lateromaculata (ROMIZ I12115). 604 
605 Figure 6. Dorsal views of select representative specimen of Glossiphoniidae from the newly

606 collected material; scale bars represent $0.25 \mathrm{~cm}$. (A) Helobdella stagnalis (ROMIZ I12030), (B)

607 Glossiphonia elegans (ROMIZ I12095), (C) Placobdella rugosa (ROMIZ I12037), (D)

608 Theromyzon rude (ROMIZ I12018), (E) Theromyzon tessulatum (ROMIZ I12109).

609

610 Figure 7. Preserved Haemopis sp. feeding on a predacious diving beetle, Dytiscus dauricus

611 (Holomuzki 1986) (ROMIZ I12122), recovered from an aquatic trap in the Albany River

612 ecodistrict. 
Table 1. Metadata for leeches collected from the far north of Ontario, deposited at the Royal Ontario Museum (ROM) or Canadian Museum of Nature (CMN).

\begin{tabular}{|c|c|c|c|c|c|c|}
\hline \multicolumn{7}{|c|}{ Family: Erpobdellidae } \\
\hline Species & Survey & Date & Latitude & Longitude & Specimens & Catalogue Number \\
\hline \multirow{2}{*}{$\begin{array}{l}\text { Erpobdella dubia } \\
\text { (Moore and Meyer } \\
\text { 1951) }\end{array}$} & $\begin{array}{l}\text { Aquatic } \\
\text { Net }\end{array}$ & 20-Jun-2013 & 53.592 & -88.364 & 1 & ROMIZ I12101 \\
\hline & Unknown & 24-Jul-1965 & 55.333 & -87.283 & 1 & CMNA 1987-0646 \\
\hline \multirow{9}{*}{$\begin{array}{l}\text { Erpobdella } \\
\text { obscura } \\
\text { (Verrill 1872) }\end{array}$} & \multirow{9}{*}{$\begin{array}{l}\text { Aquatic } \\
\text { Trap }\end{array}$} & 6-Jun-2010 & 52.981 & -87.926 & 1 & ROMIZ I12119 \\
\hline & & 13-Jun-2010 & 52.560 & -87.300 & 5 & $\begin{array}{l}\text { ROMIZ I10631, } \\
\text { I10632, I10633, } \\
\text { I10634, I10636 }\end{array}$ \\
\hline & & 15-Jun-2010 & 52.560 & -87.298 & 2 & ROMIZ I12110, I12111 \\
\hline & & 23-Jun-2010 & 52.340 & -86.163 & 2 & ROMIZ I12105, I12106 \\
\hline & & 30-Jun-2011 & 52.826 & -94.215 & 1 & ROMIZ I12002 \\
\hline & & 30-Jun-2011 & 52.827 & -94.217 & 2 & ROMIZ I12011, I12012 \\
\hline & & 16-Jul-2011 & 53.907 & -93.214 & 1 & ROMIZ I10630 \\
\hline & & 20-Jun-2014 & 54.752 & -89.363 & 1 & ROMIZ I12091 \\
\hline & & 22-Jun-2014 & 54.752 & -89.364 & 1 & ROMIZ I12092 \\
\hline
\end{tabular}




\begin{tabular}{|c|c|c|c|c|c|c|}
\hline & & 23-Jun-2014 & 54.441 & -87.902 & 1 & ROMIZ I12081 \\
\hline & & 23-Jun-2014 & 54.441 & -87.901 & 1 & ROMIZ I12080 \\
\hline & & 25-Jun-2014 & 55.482 & -87.880 & 1 & ROMIZ I12086 \\
\hline & \multirow{7}{*}{$\begin{array}{l}\text { Aquatic } \\
\text { Net }\end{array}$} & 5-Jun-2010 & 52.983 & -87.932 & 1 & ROMIZ I12112 \\
\hline & & 5-Jun-2011 & 53.198 & -89.112 & 1 & ROMIZ I12067 \\
\hline & & 17-Jun-2011 & 54.456 & -90.365 & 1 & ROMIZ I12051 \\
\hline & & 21-Jun-2011 & 54.456 & -90.365 & 1 & ROMIZ I12055 \\
\hline & & 11-Jul-2011 & 52.456 & -91.820 & 1 & ROMIZ I12071 \\
\hline & & 11-Jul-2011 & 53.602 & -93.538 & 1 & ROMIZ I12022 \\
\hline & & 23-Jun-2014 & 54.443 & -87.898 & 1 & ROMIZ I12083 \\
\hline & Incidental & 9-Jul-2011 & 53.602 & -93.537 & 1 & ROMIZ I12006 \\
\hline & \multirow{3}{*}{ Unknown } & 24-Jun-1920 & 50.733 & -81.483 & 1 & CMNA 1900-5992 \\
\hline & & $\begin{array}{l}\text { 14-15-July- } \\
1920\end{array}$ & 51.267 & -80.617 & 3 & CMNA 1900-5993 \\
\hline & & $\begin{array}{l}\text { 22-Aug- } \\
1979\end{array}$ & 51.483 & -80.45 & 1 & CMNA 1988-0132 \\
\hline \multirow{2}{*}{$\begin{array}{l}\text { Erpobdella parva } \\
\text { (Moore 1912) }\end{array}$} & $\begin{array}{l}\text { Aquatic } \\
\text { Net }\end{array}$ & 7-Jul-2011 & 52.462 & -91.820 & 1 & ROMIZ I12072 \\
\hline & Unknown & 27-Jul-1965 & 55.283 & -85 & 1 & CMNA 1978-0329 \\
\hline
\end{tabular}




\begin{tabular}{|c|c|c|c|c|c|c|}
\hline \multirow{5}{*}{$\begin{array}{l}\text { Erpobdella } \\
\text { punctata } \\
\text { (Leidy 1870) }\end{array}$} & \multirow{2}{*}{$\begin{array}{l}\text { Aquatic } \\
\text { Net }\end{array}$} & 9-Jun-2011 & 54.164 & -92.044 & 1 & ROMIZ I12062 \\
\hline & & 28-Jun-2014 & 55.482 & -87.881 & 1 & ROMIZ I12087 \\
\hline & Incidental & 11-Jun-2011 & 53.752 & -88.919 & 1 & ROMIZ I12013 \\
\hline & \multirow[t]{2}{*}{ Unknown } & $\begin{array}{l}\text { 14-15-July- } \\
1920\end{array}$ & 51.267 & -80.617 & 1 & CMNA 1900-5968 \\
\hline & & 12-Jul-1965 & 52.217 & -81.8 & 1 & CMNA-1978-0328 \\
\hline \multirow{11}{*}{ Erpobdella sp. } & $\begin{array}{l}\text { Aquatic } \\
\text { Trap }\end{array}$ & 26-Jun-2014 & 55.582 & -87.877 & 1 & ROMIZ I12075 \\
\hline & \multirow{10}{*}{$\begin{array}{l}\text { Aquatic } \\
\text { Net }\end{array}$} & 5-Jun-2010 & 52.782 & -85.679 & 1 & ROMIZ I12116 \\
\hline & & 2-Jun-2011 & 53.196 & -89.108 & 2 & ROMIZ I12064, I12065 \\
\hline & & 5-Jun-2011 & 54.431 & -89.667 & 1 & ROMIZ I12063 \\
\hline & & 17-Jun-2011 & 54.455 & -90.366 & 1 & ROMIZ I12121 \\
\hline & & 11-Jul-2011 & 53.602 & -93.538 & 1 & ROMIZ I12024 \\
\hline & & 15-Jul-2011 & 53.733 & -92.762 & 6 & $\begin{array}{l}\text { ROMIZ I12042, } \\
\text { I12043, I12044, } \\
\text { I12045, I12046, I12047 }\end{array}$ \\
\hline & & 23-Jun-2012 & 52.893 & -82.684 & 1 & ROMIZ I12069 \\
\hline & & 11-Jun-2013 & 52.586 & -89.675 & 1 & ROMIZ I12096 \\
\hline & & 1-Jul-2013 & 50.686 & -85.790 & 1 & ROMIZ I12094 \\
\hline & & 20-Jul-2013 & 51.314 & -85.748 & 1 & ROMIZ I12103 \\
\hline
\end{tabular}




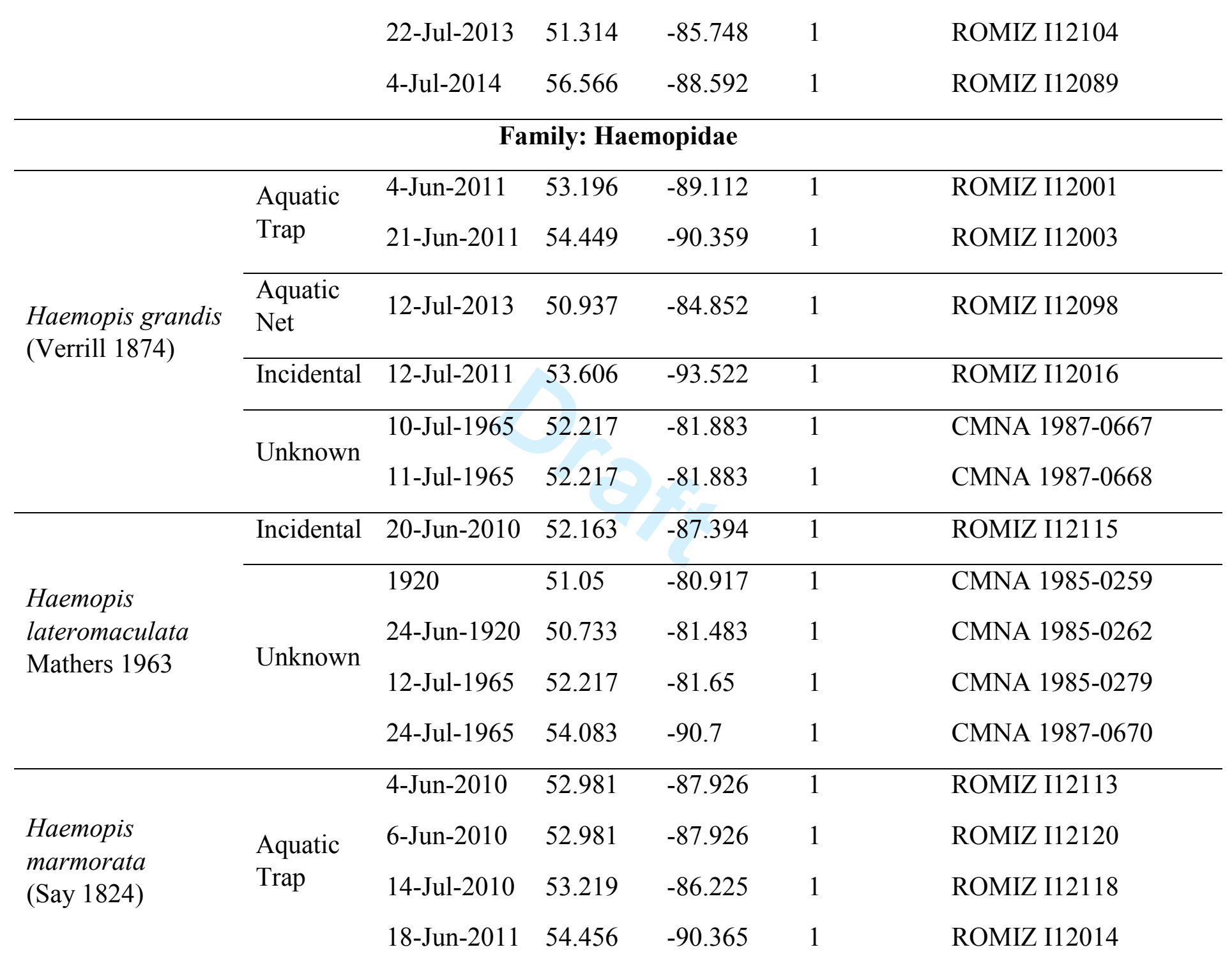




\begin{tabular}{|c|c|c|c|c|c|}
\hline & 18-Jun-2011 & 54.457 & -90.363 & 1 & ROMIZ I12017 \\
\hline & 21-Jun-2011 & 54.449 & -90.359 & 1 & ROMIZ I12004 \\
\hline & 15-Jun-2012 & 51.743 & -80.650 & 5 & $\begin{array}{l}\text { ROMIZ I12057, } \\
\text { I12058, I12059, } \\
\text { I12060, I12061 }\end{array}$ \\
\hline & 25-Jun-2014 & 55.582 & -87.877 & 2 & ROMIZ I12084, I12085 \\
\hline & 26-Jun-2014 & 55.582 & -87.877 & 5 & $\begin{array}{l}\text { ROMIZ I12074, } \\
\text { I12076, I12077, } \\
\text { I12078, I12079 }\end{array}$ \\
\hline & 28-Jun-2014 & 55.621 & -88.838 & 1 & ROMIZ I12093 \\
\hline \multirow{3}{*}{$\begin{array}{l}\text { Aquatic } \\
\text { Net }\end{array}$} & 7-Jul-2010 & 53.064 & -87.515 & 1 & ROMIZ I12117 \\
\hline & 5-Jun-2011 & 53.196 & -89.108 & 1 & ROMIZ I12066 \\
\hline & 28-Jun-2014 & 55.482 & -87.881 & 1 & ROMIZ I12088 \\
\hline \multirow{2}{*}{ Incidental } & 11-Jun-2011 & 54.164 & -92.043 & 1 & ROMIZ I12005 \\
\hline & 11-Jun-2011 & 53.753 & -88.919 & 1 & ROMIZ I12015 \\
\hline \multirow{3}{*}{ Unknown } & $\begin{array}{l}\text { 14-15 July- } \\
1920\end{array}$ & 51.267 & -80.617 & 1 & CMNA 1977-0404 \\
\hline & $\begin{array}{l}\text { 16-Aug- } \\
1920\end{array}$ & 52.283 & -81.517 & 1 & CMNA 1985-0281 \\
\hline & 11-Jun-1975 & 51.3 & -80.3 & 1 & CMNA 1986-0143 \\
\hline
\end{tabular}




\begin{tabular}{lllllll} 
& & 2-Aug-1980 & 56 & -87.717 & 1 & CMNA 1981-0062 \\
\hline & $\begin{array}{l}\text { Aquatic } \\
\text { Trap }\end{array}$ & 15-Jun-2012 & 51.743 & -80.650 & 1 & ROMIZ I12122 \\
\cline { 2 - 6 } & Incidental & 20-Jun-2010 & 52.163 & -87.394 & 1 & ROMIZ I12114 \\
\cline { 2 - 6 } & Pitfall & 13-Jul-2012 & 51.358 & -82.057 & 1 & ROMIZ I12073 \\
\cline { 2 - 6 } & $\begin{array}{l}\text { Pan Trap } \\
\text { (blue) }\end{array}$ & 8-Jun-2013 & 52.586 & -89.677 & 1 & ROMIZ I12082 \\
\hline
\end{tabular}

\begin{tabular}{lllllll}
\hline & \multicolumn{5}{c}{ Family: Glossiphoniidae } & \\
\hline & $\begin{array}{l}\text { Aquatic } \\
\text { Trap }\end{array}$ & 23-Jun-2010 & 52.340 & -86.163 & 2 & ROMIZ I12107, I12108 \\
\cline { 2 - 7 } & & 7-Jul-2011 & 53.602 & -93.537 & 1 & ROMIZ I12040 \\
& & 12-Jul-2012 & 52.306 & -83.384 & 1 & ROMIZ I12070 \\
Glossiphonia & Aquatic & 10-Jun-2013 & 52.586 & -89.677 & 1 & ROMIZ I12095 \\
1872) Castle 1900 & Net & 20-Jun-2013 & 53.592 & -88.362 & 1 & ROMIZ I12102 \\
& & 6-Jul-2013 & 51.008 & -87.146 & 1 & ROMIZ I12100 \\
& & 10-Jul-2014 & 56.289 & -89.567 & 1 & ROMIZ I12090 \\
\cline { 2 - 7 } & & 14-Jul-1920 & 51.267 & -80.617 & 1 & CMNA 1900-8243 \\
& Unknown & 15-Jul-1965 & 52.933 & -82.6 & 1 & CMNA 1978-0327 \\
& & 22-Jul-1965 & 55.283 & -85.083 & 1 & CMNA 1978-0326
\end{tabular}




\begin{tabular}{|c|c|c|c|c|c|c|}
\hline & & $\begin{array}{l}\text { 11-Aug- } \\
1967\end{array}$ & 52.133 & -94.733 & 1 & CMNA 1987-0671 \\
\hline Glossiphonia sp. & Incidental & 9-Jul-2011 & 53.602 & -93.537 & 1 & ROMIZ I12007 \\
\hline \multirow{11}{*}{$\begin{array}{l}\text { Helobdella } \\
\text { stagnalis } \\
\text { (Linnaeus 1758) }\end{array}$} & \multirow{9}{*}{$\begin{array}{l}\text { Aquatic } \\
\text { Net }\end{array}$} & 7-Jul-2011 & 53.603 & -93.536 & 1 & ROMIZ I12041 \\
\hline & & 11-Jul-2011 & 53.602 & -93.537 & 5 & $\begin{array}{l}\text { ROMIZ I12030, } \\
\text { I12031, I12032, } \\
\text { I12033, I12148 }\end{array}$ \\
\hline & & 11-Jul-2011 & 53.602 & -93.538 & 8 & $\begin{array}{l}\text { ROMIZ I12019, } \\
\text { I12020, I12021, } \\
\text { I12023, I12025, } \\
\text { I12026, I12027, I1 } 2028\end{array}$ \\
\hline & & 15-Jul-2011 & 53.733 & -92.765 & 2 & ROMIZ I12048, I12049 \\
\hline & & 17-Jun-2011 & 54.456 & -90.365 & 3 & $\begin{array}{l}\text { ROMIZ I12052, } \\
\text { I12053, I12054 }\end{array}$ \\
\hline & & 13-Jun-2011 & 53.753 & -88.920 & 1 & ROMIZ I12056 \\
\hline & & 21-Jun-2012 & 52.893 & -82.683 & 1 & ROMIZ I12068 \\
\hline & & 25-Jun-2013 & 53.397 & -87.800 & 1 & ROMIZ I12097 \\
\hline & & 6-Jul-2013 & 51.012 & -87.154 & 1 & ROMIZ I12099 \\
\hline & \multirow[b]{2}{*}{ Unknown } & 15-Jul-1965 & 52.967 & -82.35 & 56 & CMNA 1987-0669 \\
\hline & & $\begin{array}{l}\text { 16-Aug- } \\
1965\end{array}$ & 52.933 & -82.4 & 21 & CMNA 1987-0666 \\
\hline
\end{tabular}




\begin{tabular}{|c|c|c|c|c|c|c|}
\hline Helobdella sp. & Unknown & 26-Jul-1963 & 51.267 & -80.617 & 1 & CMNA 1987-0662 \\
\hline $\begin{array}{l}\text { Placobdella } \\
\text { montifera } \\
\text { (Moore 1906) }\end{array}$ & Unknown & 5-Aug-1961 & 51.5 & -90.15 & 1 & CMNA 1987-0659 \\
\hline $\begin{array}{l}\text { Placobdella } \\
\text { rugosa } \\
\text { (Verrill 1874) }\end{array}$ & $\begin{array}{l}\text { Aquatic } \\
\text { Net }\end{array}$ & 11-Jul-2011 & 53.602 & -93.537 & 1 & ROMIZ I12037 \\
\hline $\begin{array}{l}\text { Theromyzon rude } \\
\text { (Baird 1869) }\end{array}$ & $\begin{array}{l}\text { Aquatic } \\
\text { Net }\end{array}$ & 11-Jul-2011 & 53.602 & -93.538 & 1 & ROMIZ I12018 \\
\hline $\begin{array}{l}\text { Theromyzon } \\
\text { tessulatum (Müller } \\
\text { 1774) }\end{array}$ & $\begin{array}{l}\text { Aquatic } \\
\text { Trap }\end{array}$ & 13-Jun-2010 & 52.560 & -87.298 & 4 & ROMIZ I12109 \\
\hline \multirow{5}{*}{ Theromyzon sp. } & $\begin{array}{l}\text { Aquatic } \\
\text { Trap }\end{array}$ & 11-Jul-2011 & 53.603 & -93.536 & 1 & ROMIZ I12038 \\
\hline & \multirow{4}{*}{$\begin{array}{l}\text { Aquatic } \\
\text { Net }\end{array}$} & 7-Jul-2011 & 53.603 & -93.536 & 1 & ROMIZ I12147 \\
\hline & & 11-Jul-2011 & 53.602 & -93.537 & 4 & $\begin{array}{l}\text { ROMIZ I12029, } \\
\text { I12034, I12035, I1 } 2036\end{array}$ \\
\hline & & 11-Jul-2011 & 53.603 & -93.536 & 1 & ROMIZ I12039 \\
\hline & & 15-Jul-2011 & 53.737 & -92.763 & 1 & ROMIZ I12050 \\
\hline
\end{tabular}




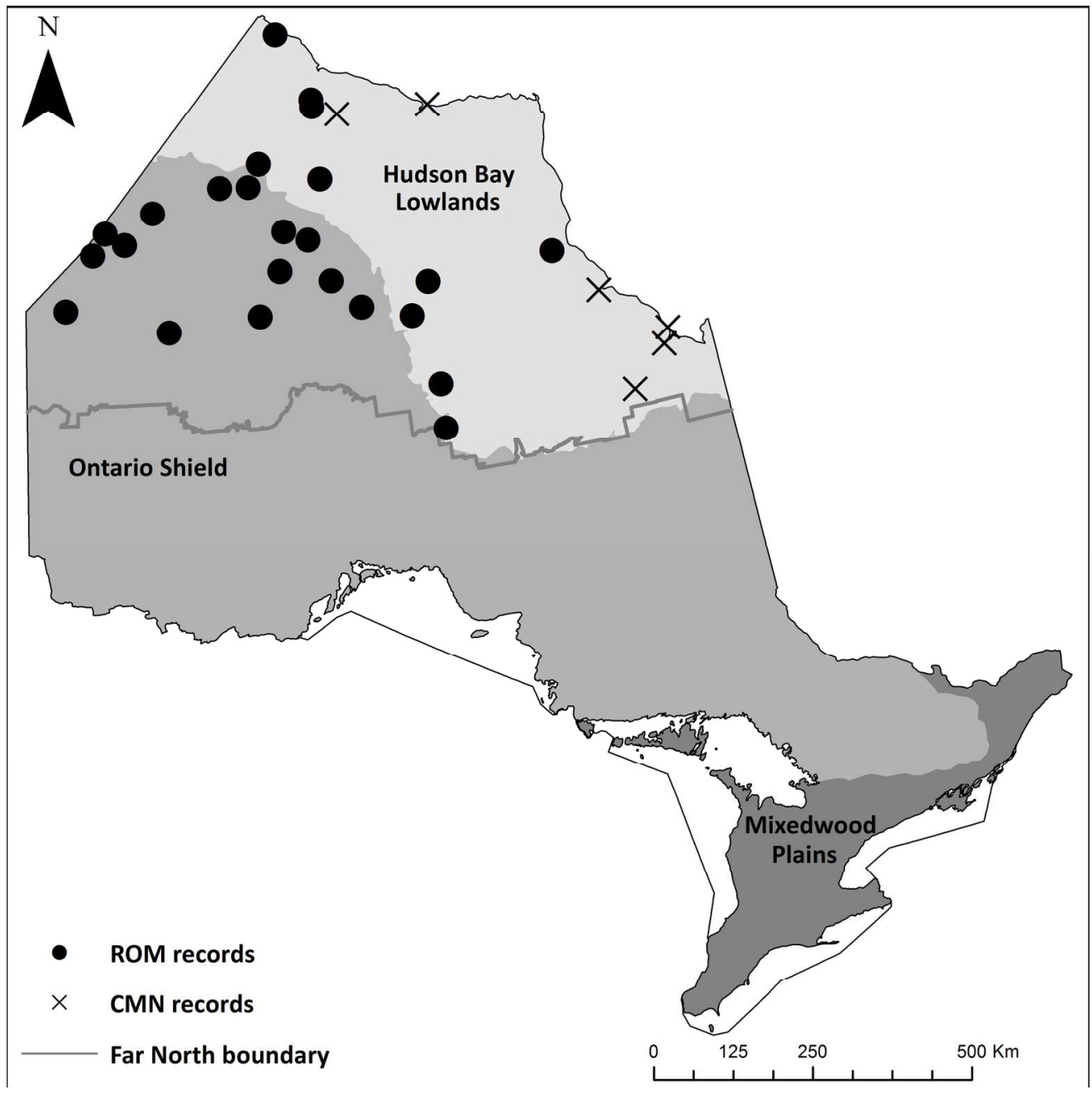

Figure 1. Distribution of leech samples of the family Erpobdellidae, collected for the present study across the far north of Ontario's two ecozones; Hudson Bay Lowlands and Ontario Shield. Projection: Canadian Lambert Conformal Conic, Datum: NAD 1983.

$170 \times 170 \mathrm{~mm}(300 \times 300 \mathrm{DPI})$ 


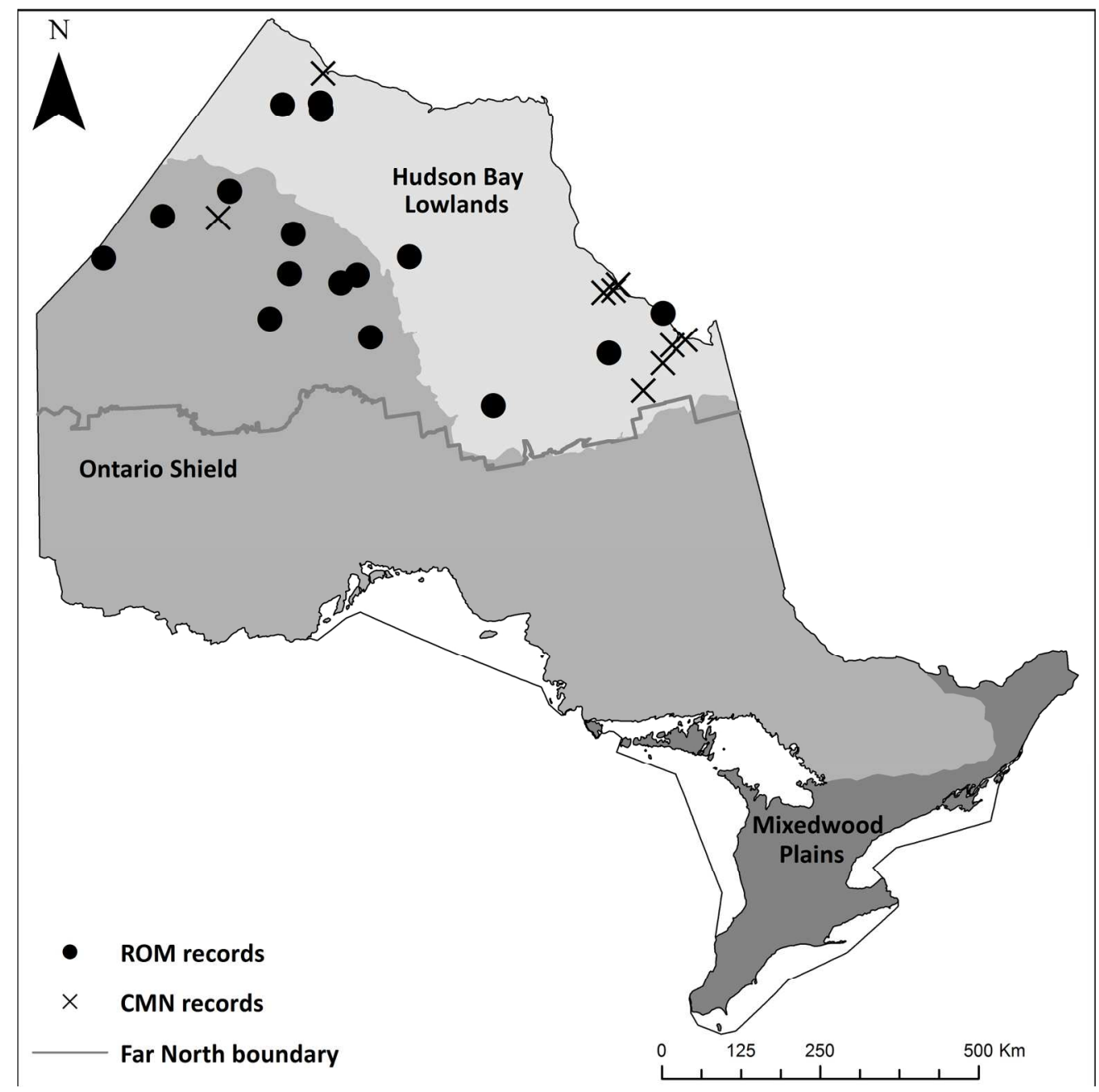

Figure 2. Distribution of leech samples of the family Haemopidae, collected for the present study across the far north of Ontario's two ecozones; Hudson Bay Lowlands and Ontario Shield. Projection: Canadian Lambert Conformal Conic, Datum: NAD 1983.

$170 \times 170 \mathrm{~mm}(300 \times 300 \mathrm{DPI})$ 


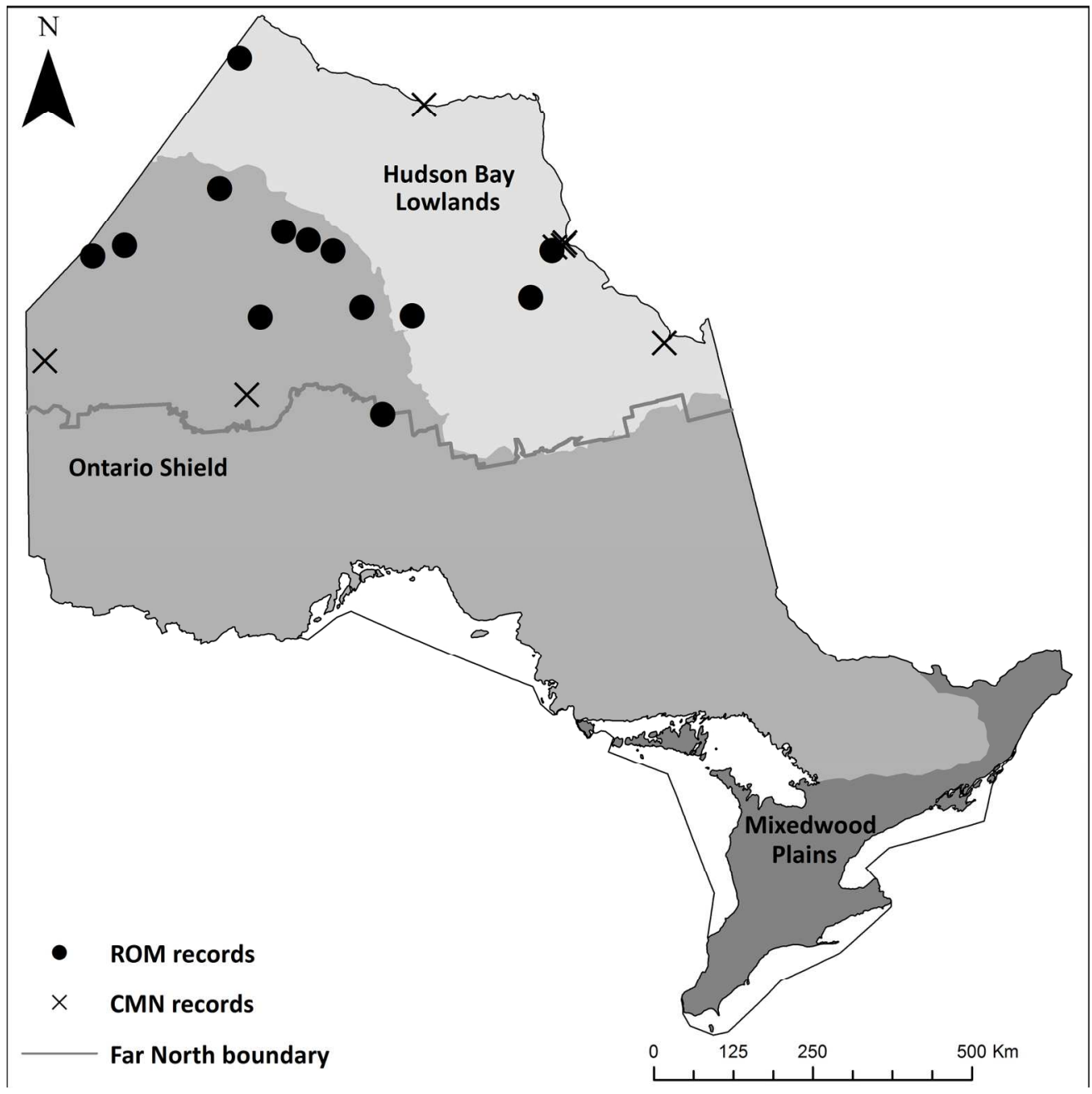

Figure 3. Distribution of leech samples of the family Glossiphoniidae, collected for the present study across the far north of Ontario's two ecozones; Hudson Bay Lowlands and Ontario Shield. Projection: Canadian Lambert Conformal Conic, Datum: NAD 1983.

$170 \times 170 \mathrm{~mm}(300 \times 300$ DPI $)$ 

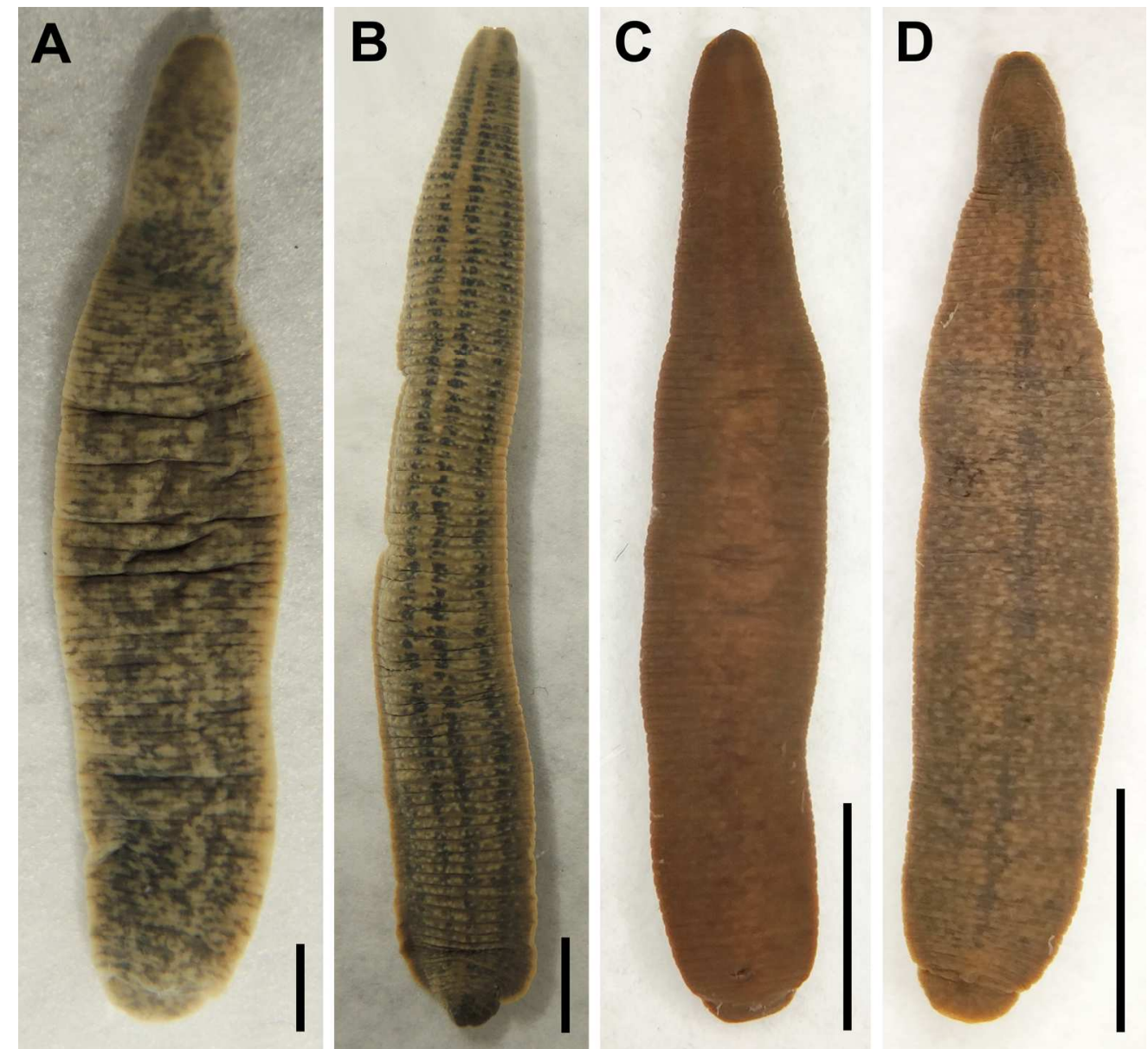

Figure 4. Dorsal views of select representative specimens of Erpobdellidae from the newly collected material; scale bars represent $0.5 \mathrm{~cm}$. (A) Erpobdella obscura (ROMIZ I12051), (B) Erpobdella punctata (ROMIZ I12062), (C) Erpobdella parva (ROMIZ I12072), (D) Erpobdella dubia (ROMIZ I12101). $160 \times 148 \mathrm{~mm}(300 \times 300$ DPI $)$ 

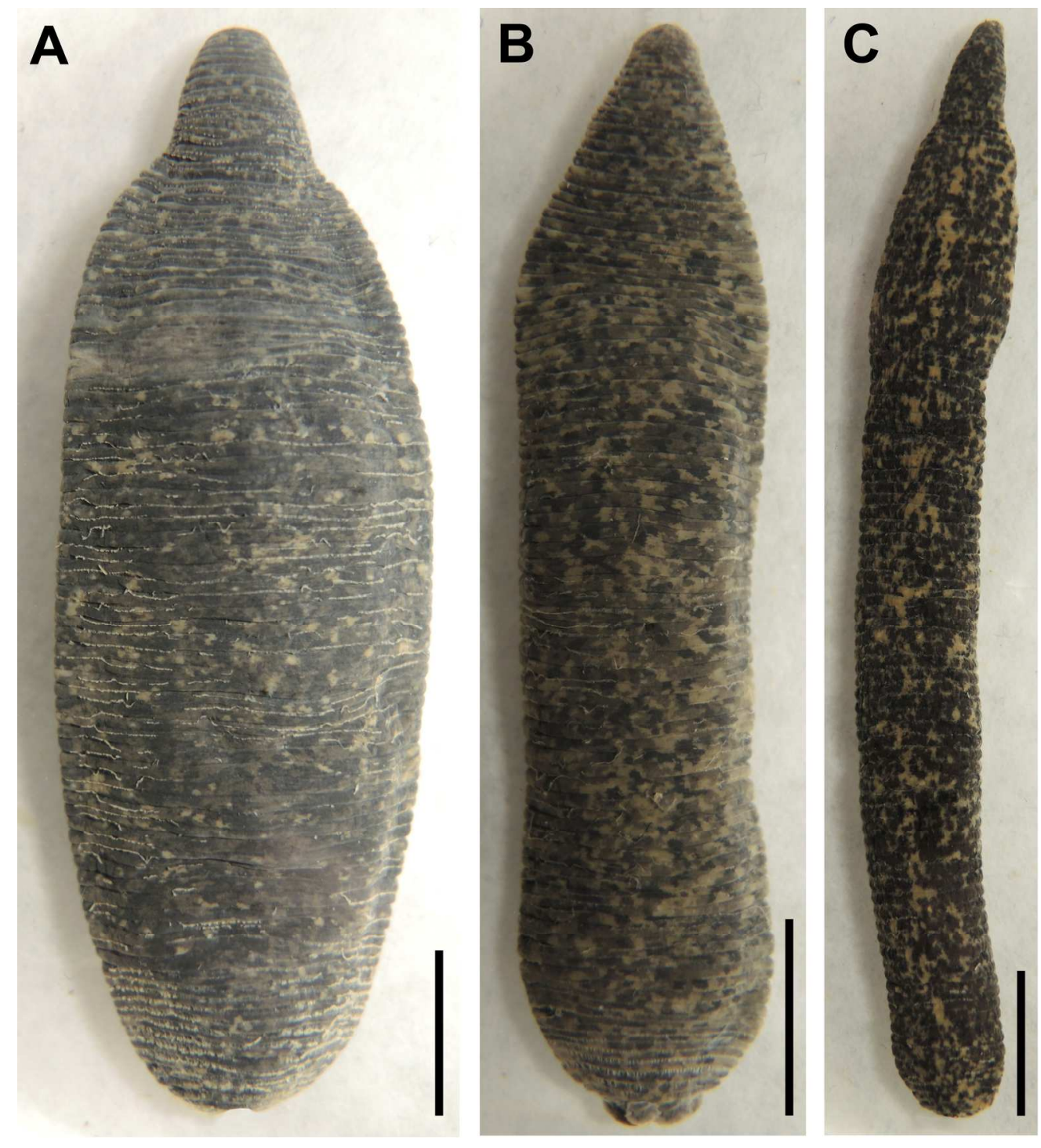

Figure 5. Dorsal views of select representative specimen of Haemopidae from the newly collected material; scale bars represent $1 \mathrm{~cm}$. (A) Haemopis grandis (ROMIZ I12001), (B) Haemopis marmorata (ROMIZ I12015), (C) Haemopis lateromaculata (ROMIZ I12115).

$179 \times 198 \mathrm{~mm}$ ( $300 \times 300$ DPI) 

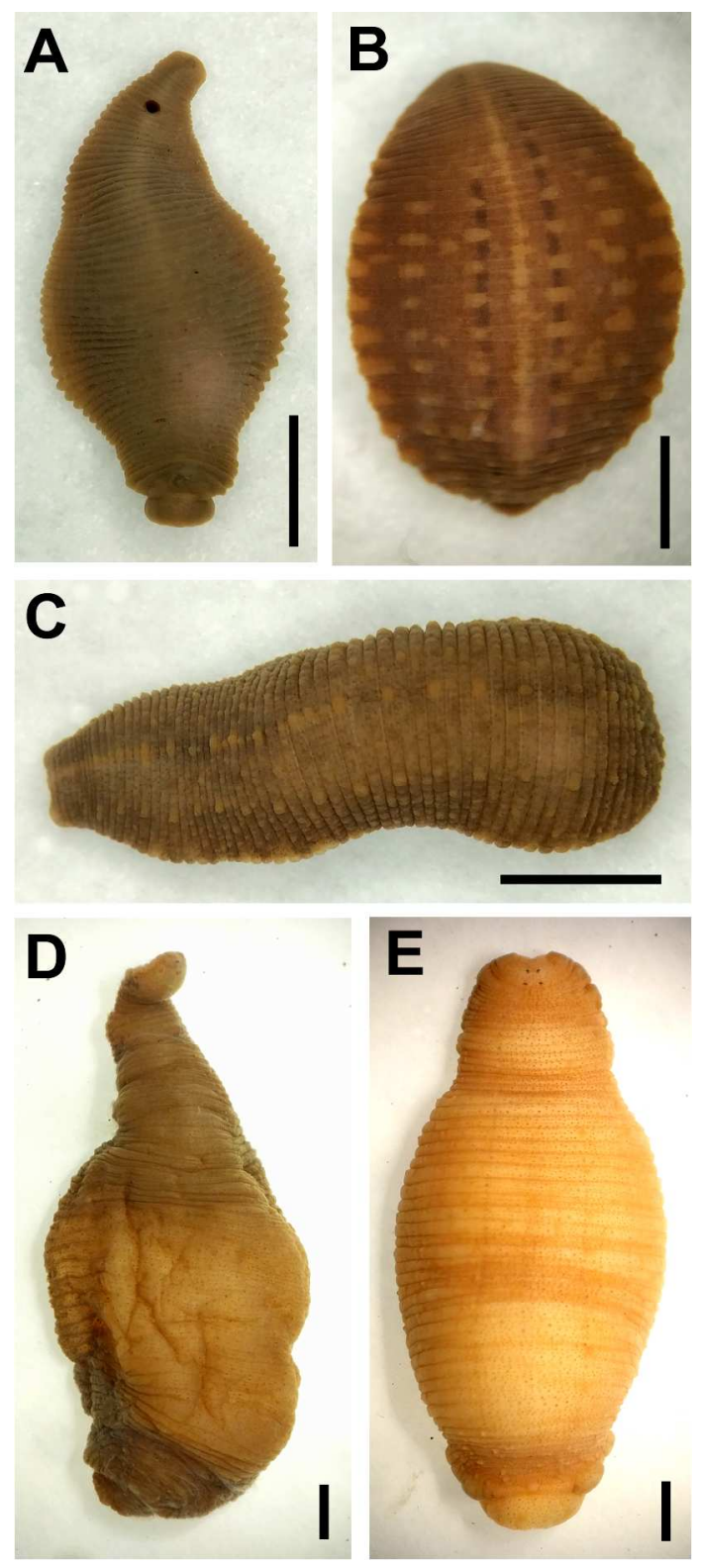

Figure 6. Dorsal views of select representative specimen of Glossiphoniidae from the newly collected material; scale bars represent $0.25 \mathrm{~cm}$. (A) Helobdella stagnalis (ROMIZ I12030), (B) Glossiphonia elegans (ROMIZ I12095), (C) Placobdella rugosa (ROMIZ I12037), (D) Theromyzon rude (ROMIZ I12018), (E) Theromyzon tessulatum (ROMIZ I12109).

$$
213 \times 488 \mathrm{~mm}(300 \times 300 \mathrm{DPI})
$$




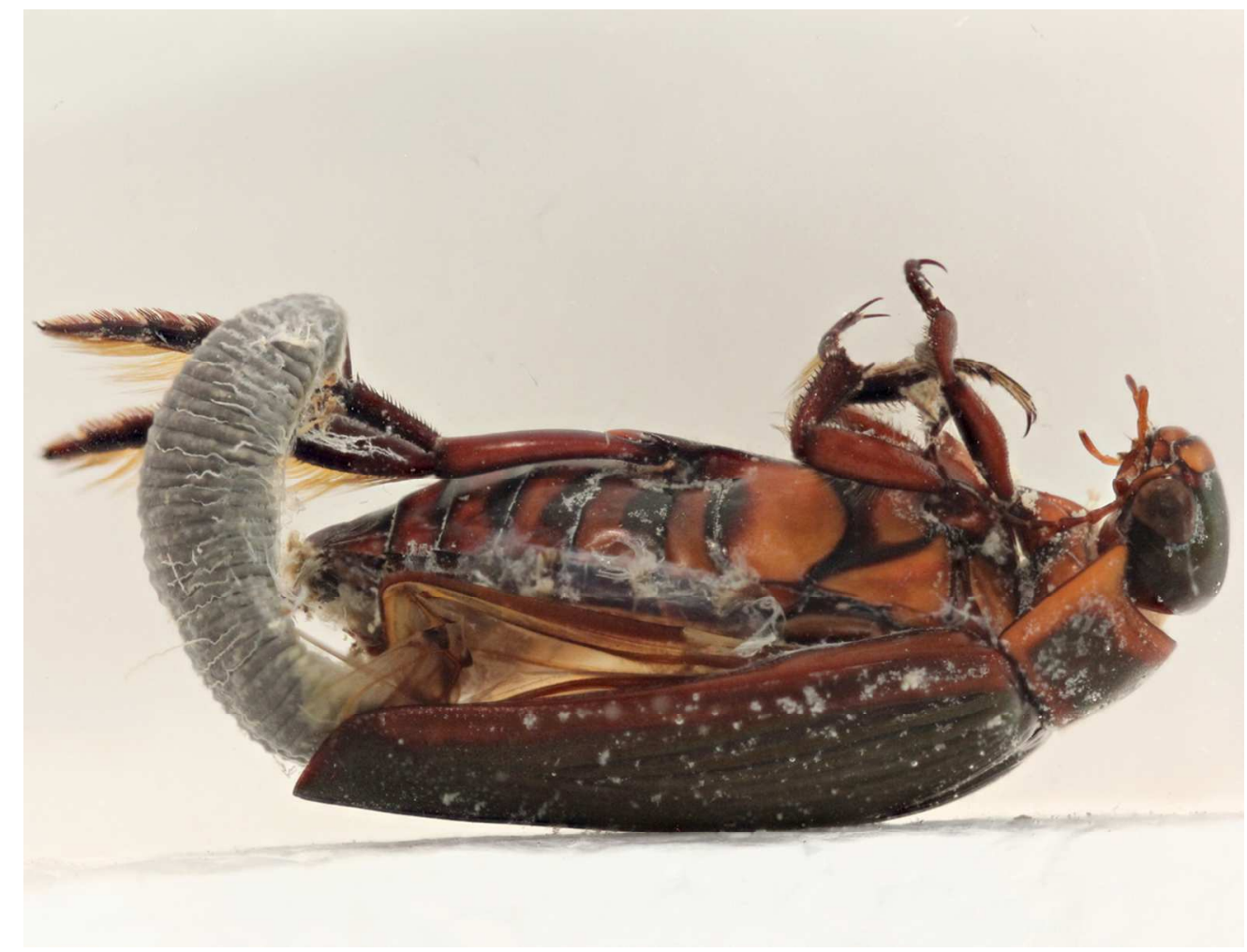

Figure 7. Preserved Haemopis sp. feeding on a predacious diving beetle, Dytiscus dauricus (Holomuzki 1986) (ROMIZ I12122), recovered from an aquatic trap in the Albany River ecodistrict.

$109 \times 84 \mathrm{~mm}(300 \times 300 \mathrm{DPI})$ 